\title{
6. Life imitating art: Asian romance movies as a social mirror
}

ABSTRACI

As a genre of mass media, the romance movie has the potential to influence and shape audience's views on socio-cultural issues of the time (Rahman, 2013). Asian romance movies often depict behaviours that challenge thei moral code such as obeying authority, adherence to cultural norms and putting society before self. For dramatic effect, such movies would often showcase scandalous themes and socially objectionable behaviours which are eventually resolved, indicating a return to socially accepted codes of conduct. There is a clear appreciation of values considered ideal in romantic partnerships including honesty and fidelity. Interestingly, such movies appear to capture the Asian diaspora, challenging social norms and negotiating its values, behaviours and beliefs against foreign elements. This article explores the scandals and consequences portrayed in some of these Asian movies, evaluating the effect this might have on their actors and a receptive audience. Elements of scandal in the personal lives of some of the actors make a case for life and art imitating the other in a cycle of challenge, compromise and conformity.

Keywords: Asian romance movies, celebrity, scandal, collective representation, media representation, morality,

KHAIRIAH A RAHMAN

Auckland University of Technology

SIAN ROMANCE movies have captured social shifts in cultural
values of their times, from adaptation of their rich colonial herit-
age to their emerging global cultural diaspora. With its inhabitants making up 60 percent of the world's population, Asia is the world's largest continent with large numbers of its population migrating to locations within Asia, America and Europe. A United Nations report on Human Development in 2000 noted that 15.69 million Asians were living in Europe, 9.57 million in North America, 1.29 million in Oceania and 1.07 million in Africa, with

PACIFIC JOURNALISM REVIEW 19 (2) 2013107 


\section{CELEBRITY AND SCANDAL}

35.49 million moving within Asia for work opportunities (The Economist, 2009). These movements were significant as they indicate the growth of an Asian diaspora. More significantly, there appears to be a strong connection between these groups who have left their countries of origin and the ties they continue to maintain. For example, Asians from North America sent remittances amounting to US\$30.1 billion back to Asia (The Economist, 2009). In 2010, the World Bank (Migration and remittances factbook, 2011) reported that three of the top five receivers of world remittances were Asian countries - India (US\$55 billion), China (US\$51 billion) and the Philippines (US\$21.3 billion). In terms of human capital and economic development, Asia is resilient, economically-driven and responsive to global changes. The Asian diaspora is flourishing yet the connection to the home country and sense of cultural identity appear to be strong. With Asian people experiencing extensive cultural exposure and adaptation, their movies have a tendency to include experiences of the Asian culture in transition. It is no wonder that Asian movies today tell stories for an international audience, capturing the Asian psyche as it negotiates its place in the scheme of intercultural influences.

Across Asia, popular culture favours the hero and heroines of films. The tabloid press of the English-speaking world, with its celebrity news, has its place in Asia where English is often the lingua franca for intercultural dialogue. Entertainment news in the media is no different from other outlets worldwide, seeking to satisfy the celebrity interest news value of the curious and adoring public. Often, the stories in such tabloids would centre around current leads and their love lives, casting a close resemblance to the characters they play. The romance movies themselves centre on themes which affect society, defining their world view and relevance. In a study of the cultural themes in nine Asian romance movies, Rahman (2013) notes their role 'as a societal record that traces the developments of a cultural debate, the negotiation of social meaning, the perceived collective cognition and the resolution of conflicts' (p.1). Indeed, Asian cinema is a complex blend of traditional and emerging cultures, old and new, local and global, urban and rural, presenting a range of multiple identities. As Ciecko (2006) points out:

Asia is extremely culturally diverse in terms of languages, religions, political systems, and cultural practices; therefore the suggestion of monolithic culture and homogeneity is extremely fraught. (Ciecko, 2006, p. 4)

108 PACIFIC JOURNALISM REVIEW 19 (2) 2013 
Historically, much of Asia has been colonised, sharing a history of nationhood struggles. Indeed, the term 'Asian' has been used to different ends - to convey shared cultural attributes or experience, geographical origins, and/ or race' (Ciecko 2006, p.4). For countries in Asia, independence has shaped their shared national consciousness, leading to the formation of ASEAN (Association of the South East Asian Nations) in 1967 by five member countries that have since grown to 13 , all pledging mutual cooperation in trade, cultural exchanges and defence. The close partnerships and shared perspectives mean the issues raised in Asian romance movies are perceptibly similar, covering issues such as the impact of social media, individualist tendencies, national and cultural identities. Examples from Thai, Malay and Indian movies will be used for discussion to illustrate the content of scandal in the Asian cultural diaspora and negotiation of moral identity. Reports on the life of the actors and of some of these movies will also be analysed to scope the content of media and public interest in celebrity stories and discuss its impact.

\section{Romance movies and the power of influence}

Romance movies generate a lot of activity on the internet showing a clear following across Asian cultures. There were 10.3 million sites on Malay romance movies, 20.8 million for Thai movies and 52.2 million for Indian movies.

Audiences who favour the romance genre over other movie types can be seen as participants of a social event and witnesses to the struggles and joys of the principal actors. In melodramatic cases, moved by unjust turns of events, the audience often reacts emotionally such as crying or talking about what disturbs them. This heightened sense of social engagement is what Durkhheim (1912/1995) refers to as 'collective effervescence'. Traditionally coined to capture people's reaction and participation in emotionally charged social events such as a spiritual gathering, the term also captures the power of the event to influence and invoke emotions, enforcing specific shared values and world view.

In media ethics, producers of media content should responsibly represent their target audiences' socio-cultural experience. There are numerous global studies demonstrating the correlations between media depiction of content and changes in social behaviours (Vasan, 2010). In her study on the influence of film and TV on young people in India, Vasan (2010) reported that 'studies in the Indian context have found that films and TV are an integral part of 


\section{CELEBRITY AND SCANDAL}

youth sub-culture' (p.5). She further cited a study done by the World Health Organisation (2003) in Delhi and Mumbai to determine the influence of Indian cinema on teenage behaviour where it was found that 'films serve as a medium through which young people are presented with new ideas about dress codes, behaviour or attitude which they often imitate and use in their daily interactions with friends and acquaintances' (Vasan, 2010, p.6, citing WHO, 2003). More importantly, the study noted that 'films have created a yearning for romance'.

With the entry of foreign cultural elements, stories of young people often reflect individual struggles against the collective group. This struggle to assert their new world view is often given some consideration before reality sets in to re-establish society's law. The enforcement of messages considered socially acceptable echoes through several Asian movies, across cultural groups, suggesting a conscious and deliberate effort by media creators to uphold a measure of social collective representation. This idea of morality driven by social sanction rather than individual belief was introduced by Durkheim. It sees society as playing a central role in explaining human thought and behaviour. Just as an abstract representation such as the national flag means nothing without the patriotism attached to it by a collective group, so is specific behaviour meaningless unless given a moral perspective by collective social agreement. This is a form of 'cultural determinism' that is external to the individual and has the power to influence. As Alex (2001), comments, 'society exercises considerable powers of collective creativity far exceeding those of any individual genius, who at any rate is always formed within society' (p.57).

The Asian romance movies also show a 'conscience collective' at work, where media creators appear to support a cause of action as being right. The term 'conscience collective' was coined by Durkheim in his philosophical discussion of religion and society. It indicates a shared value by a social group where moral beliefs are attached to its meaning.

While 'collective effervescence' is an unconscious process of emotional fervour, 'conscience collective' is a conscious one which seeks to determine and uphold what is considered fair, just and right (Alex, 2011, p.57). Reinforcement of such messages over time is likely to set the tone for social acceptance unless such views are contested and a different viewpoint is presented to the audience.

According to Moscovici's (2000) idea of social representation, the individual also has power to access multiple sources of influence and drive 
cultural formation through interaction. Media and citizen reports on scandals involving Asian actors in the local and international scene can influence the audience's perspective on moral issues. While the individual is seen as a critical player in cultural development, negotiating its 'dynamic and changeable character', it still answers to a wider group as it addresses the 'common ways of conceiving, thinking about and evaluating social reality' (Höijer, 2011, p. 4). The individual is in fact often influenced by social groups, the impact of moral decisions is not just felt by the individual audience but by the romantic actors themselves. For example, in the final movie by the late legendary Bollywood director Yash Chopra, released in 2012, Jaab Tak Hai Jaan (As long as there is life), the lead actors broke tradition by agreeing to participate in sexually explicit scenes. Unlike the usual 'fake kiss' and 'fade out' takes of the past, the love scenes required semi-nude body contact as well as close shot kissing scenes. Sharukh Khan, the lead actor, was apparently known for his no-kissing rule which he broke for the film. According to Indo-Asia News (2012): "The superstar says he was "forced" to kiss this time, and says it was only a demand of the script'. Despite his own self-set rule, Khan gave in to social pressure, reflecting that, 'they knew I was awkward, I had issues and I am a very easy actor to work with. They are like my family and they said, "You don't have to do this" and then they got together and they forced me and then even paid me for it' (Indo-Asia News, 2012). Khan further qualified the act by mentioning his close relationship with the late director who asked him to perform the scene 'as a requirement' and that the act itself was 'mechanical' (Indo-Asia News, 2012).

One way of conceptualising the willing participation in social coercion is Habermas's idea of cultural hermeneutics and the concept of 'lifeworld'. Our views on life are non-static and open to cultural interpretation, something which the media captures and mirrors. The point with media representation is the framing of one perspective, by a person or group that may or may not give a full depiction of reality, depending on whose reality it is (Rahman, 2013). In the Asian romance movies, challenges to moral questions are often resolved to align with existing cultural hegemony, offering a real potential to influence as 'the media continues to be used as a vehicle for cultural representation, sending powerful verbal and visual messages about lifestyles, practices and symbols of people, forging identity, encouraging unity, creating impressions and reinforcing stereotypes' (Rahman \& Thomas, 2011, p. 96). 


\section{CELEBRITY AND SCANDAL}

\section{The Asian romance movies: Of scandals and their moral messages}

Asian romance movies traditionally promote collective moral standpoints. In a study of Asian romance movies screened between 2010 and 2012, Rahman (2013) found that 'despite each movie's initial promotion of individualistic tendencies, there is a clear reference to the collectivist framework and socially acceptable norms and values' (p.22). These individualistic tendencies may be seen as scandalous behaviours requiring a return to social decorum. Scandals portrayed in Asian romance movies include challenging the cultural, religious and national identity as well as the role of the family and collectivist society.

Some Asian romance movies associate symbols of foreign influence and modernisation with scandals that threaten the cultural-national identity. For example, the Malay romance movie Cun (Attraction) captures the paddy fields of the village scene against the Kuala Lumpur Twin Towers, contrasting two distinct lifetyles - the decadent city and the wholesome country while depicting the traditional and modern dress codes to show the changing Malay cultural landscape. The story tells of how a lead female reporter and host of a celebrity talk-show suffers an emotional break-down when her fiancé, the country's leading actor, is caught on camera in a scandalous affair with an aspiring new starlet. She escapes to the village and falls in love with a landrich farmer who practises eco-friendly agriculture. The girl's dressing shifts between her modern dresses and the traditional baju kurong (long-sleeved tops and long skirts) to suggest adjustment to bi-culturalism. What may be viewed as scandalous to traditional practice is the marriage proposal itself, as the girl returns to the village to propose to her man. Traditionally, marriage is a collective process, initiated by the man and involving the wider social group. In this case though, the girl initiates the ceremony without her family. The movie reconciles the lifestyles of the city and country as part of the Malay national identity while allowing for a new perspective to the marriage process, potentially passing off scandalous behaviour as emerging norm. However, the couple's behaviour is supported by his conservative family, portrayed as religious country folk, thus gaining social sanction.

In Istanbul Aku Datang (Istanbul, here I come), scandals are played out in the lives of Malaysian tertiary students living abroad. The young female traveller moves to Turkey in the hopes of marrying her fiancé. She does not see the harm insharing accommodation with her fiancé and his male friends and challenges her fiancé's point about what society might think, showing a

112 PACIFIC JOURNALISM REVIEW 19 (2) 2013 
clear struggle of self interest against collective interest. In her struggles, she encounters symbols of her national identity, such as the Malaysian flag, the Malaysian Mee Laksa and a man dressed in the traditional Malay headgear for prayers. These are reminders she belongs to a wider collective group and must answer to the issue of moral standards of behaviour.

A scandal involving the female traveller's fiancé is exposed when it is revealed he has a Turkish girl friend. It explains his moral irregularity when he pretends to behave decently with his fiancée in public and tries to take advantage of her in private. The movie clearly cautions young people to be steadfast in their moral decisions, affirming the place of accepted social conduct.

In Jaab Tak Hai Jaan, (As long as there is life), there are scandals on multiple levels, including cultural values, national and religious identity. The hero, Samar, runs away to London as a migrant to escape conscription into the Indian army. A failed love affair in London sees him back in India, serving 10 years as a fearless major in the Indian army's bomb disposal unit, resolving the hero's national identity crisis. Another scandal involves the clandestine affair between the rich, upper-class and native English-speaking heroine Meerah and the odd-job migrant labourer, Samar. Meerah gives up playing the filial daughter by falling in love with Samar instead of marrying a man her father has chosen for her. Circumstances force their separation and through several plot twists, Samar meets Akira, a young female Discovery Channel reporter who falls for him and offers herself. There is scandal in her flippant attitude towards men and her casual offer of sex. In contrast, Samar maintains unwavering love for Meerah whose love for Samar is equally constant. Akira witnesses their heart-wrenching tests and enduring love, reaffirming the values of loyalty, fidelity and trust.

Religious identity is also challenged in Jaab Tak Hai Jaan, when Meerah breaks her promise to God and develops a forbidden passionate affair with Samar, despite being engaged to a man of her father's choice. Samar meets with an accident which Meerah sees as God's punishment to their transgressive relationship and she leaves Samar to 'protect his life'. Samar challenges the notion of God as spiritual trader and objects to Meerah's wagering, trading love for life and allowing superstitions to rule their relationship. Eventually, Meerah realises her foolishness and returns to Samar. The movie reveals a strong sense of self-empowerment in Meerah's decision which calls for a reinterpretation of her religious beliefs. 


\section{CELEBRITY AND SCANDAL}

In Aku Terima Tikahnya (I accept this marriage), a husband agonises over the concepts of halal and haram (what is permissible and forbidden), after he loses his short-term memory and is unable to recall his wedding vows, thus believing his wife is forbidden to him. Unable to bear the idea of living in sin, the husband decides to leave the wife. The estranged couple turns to God in fervent prayer and surrender and the story fittingly ends with the couple reuniting. The movie's message is that of spiritual steadfastness. The scandal of the actors' on-screen chemistry later became the subject of tabloid news, especially when the leading lady was newly divorced and the lead actor was married.

In the Thai romance movie Seven Something, a scandal affects the relationship of two young lovers struggling to handle their relationship in the social media. The boy cannot seem to distinguish between private and public spaces. As an aspiring cameraman, he is driven by popularity votes through the number of 'likes' on his YouTube uploads and decides to publish a personal video in which his girlfriend reveals her feelings for him. The scandalous act of wooing a boy is newsworthy and the public laughs at her expense. Although the boy takes down the video, several bloggers had downloaded it and before long, the video goes viral, effectively ending his relationship with the girl. The movie forces the audience to consider cultural values of face-saving and respect for others over self-benefit.

In another Thai movie Hello Stranger, there are scandals in the lifestyle and conduct of two strangers who meet in Korea and end up travelling together. We see the hero and heroine negotiating cultural differences and uncertainties. The hero shows cultural incompetence when he carries a Korean bride during a wedding ceremony, an act only meant for her groom. The story is reflective of the Asian abroad, of the tensions of diaspora and the problems of adjusting to another culture.

Throughout their travels, the couple shares scandalous ideas of love and marriage. The hero challenges the institution of marriage while the heroine breaks up with her fiancé because she feels justified in lying to him. The story is full of negotiation of trust issues but predictably ends with the hero deciding he does believe in marriage with the right partner while the heroine sees the value of honesty. The couple eventually finds one another on their return to Thailand, once again reaffirming the norm, firmly supporting the institution of marriage. 
In Asian societies, the family plays a critical moral support role in the social structure, with parents taking prominent positions as elders in the family unit. This is mirrored in Asian romance movies, where parents play the roles of counsellors and advisors. For example, in the Malay movie, Aku Terima Nikahnya (I accept this marriage), both the families of the bride and groom listen to their respective problems, ever-ready to empathise and dispense advice, usually of a religious nature. Even the characters who seem to function independently of their families reach out to an immediate network of culturally similar people while abroad. This is evident in the romance movies Istanbul Aku Datang, Hello Stranger and Jaab Tak Hai Jaan.

Scandals that challenge the role of the parent, authority and homosexuality affect the collectivist society in the Bollywood movie Student of the Year. The school's sponsor, respected business tycoon and father to one of the students (Rohan), is in fact a poor role model as a parent; he is unsupportive, arrogant and a bully to his subservient wife. Rohan stands up to his father and makes a name for himself in the music industry something his father disapproves of. Another scandal involves the Dean who turns out to be a homosexual with romantic inclinations towards the school's unsuspecting soccer coach. There is a further scandal when a drunken student, Sudo, insults their Dean for failing to devise a fair assessment at the award ceremony. This results in public embarassment, forcing their once well-loved and respected Dean to resign from his position and live in obscurity. The story ends with the Dean on his deathbed forgiving his ex-students and dreaming of a future where his love might be returned. While supporting the resistance against unjust elders, the movie silences homosexuality as foreign to the lived cultural experience of the present.

Where the family has failed the hero or heroine, the wider social support steps in to provide solutions and coping strategies. In the Thai movie First Love, the heroine, Nam, has girlfriends who stand by her as she struggles with her insecurity issues. Such stories reinforce the value of friends in emotional support roles, promoting the idea of putting others before self. For example, Shone does not express his love for Nam as he has promised his best friend, Top, that he will not pursue the girl (Nam) that Top has loved and lost. There is a pervading sense of morality for the collective good in such Asian romance movies where honour, trust and loyalty are seen as key attributes of good character. 


\section{CELEBRITY AND SCANDAL}

\section{Celebrity and the hero: When reel becomes real}

The distinction between the hero and the celebrity is often blurred. The heroic characters have been so well embodied by the actors that audiences tend to believe they know their favourite celebrities. Media exposure has granted actors their celebrity status, made them public property and compromised their privacy. As Hellmueller \& Aeschbacher (2010) note:

Celebrities become a part of the public sphere and therefore public interest. As a result, people touch them physically, randomly speak to them on the street, ask for autographs, call them by their first names, and take pictures with electronic devices (e.g., cell phones) without asking for permission. (Hellmueller \& Aeschbacher, 2010, p. 25)

The lives of these actors are scrutinised by the paparazzi and the interested public. Bollywood heartthrobs Shah Rukh Khan and Salman Khan have close to five million followers on Twitter, while their female counterparts such as Deepika Padukone and Priyanka Chopra have more than four million followers. With direct access to their celebrities, followers become both consumers and producers of celebrity media content. Hellmueller \& Aeschbacher (2010) cite a study in Belgium which showed that 'consumption of certain media outlets (newspapers, gossip magazines, and television) correlates positively with the interest in celebrity gossip' (p. 22).

As a celebrity needs the media to create positive exposure and public interest, the relationship between the celebrity, the media and the public is highly interdependent. The celebrity who is typecast as the romantic actor in popular romantic movies must appreciate his impact on the collective conscience of his audience. Any act off-screen seen as a transgression of expected behaviours may result in negative news stories and collective disappointment of the audience he serves. When heroes of Asian romance movies are suspected of inappropriate behaviour, media wheels work over time, spreading stories and looking for confirmation from varying sources such as when Shah Rukh Khan was rumoured to have a relationship with his then co-star Priyanka Chopra in early 2012 (Khan, 2012). The couple's behaviour when relating to one another became the focus of tabloid news, with Khan accused of allowing his on-screen chemistry to overflow off-screen. The media machinery uses and abuses the celebrity as magnets for its own popularity. Encouraged by Khan's readership pull, Hindustan Times ran a story titled, 'Shah Rukh Khan:

116 PACIFIC JOURNALISM REVIEW 19 (2) 2013 
Top 15 controversies he has courted' (New Delhi, June 18, 2013). The media watch an actor for the slightest information to boost readership, which does not help an actor who forgets to be himself. In fact, Khan is such a prolific actor that he often, by his own admission, plays someone else more than he does himself. As Khan's Twitter update on 3 August 2013 states: 'I think that an actor's life in İndia is best described by the game Hop, Skip and Jump. Hop on a film ... Skip normal life \& Jump to the next!'

The lead actors of Cun have also had their share of scandal. Remi Ishak, a popular lead actor of Malay romantic movies, has had his personal life analysed and reported in tabloid media. Ishak has been linked to his leading lady in $\mathrm{Cun}$, Maya Karin, who was married. She eventually divorced her husband, which media observers attributed to her on-screen and off-screen close relationship with Ishak. While tabloid press in Malaysia continues to speculate on his love interest, Ishak remains non-committal, focusing instead on his movies. As a Muslim, Ishak is expected to behave modestly, in accordance with Islamic propriety, but the media reported that he participated in a homosexual scene during his early acting days, a mistake his fans seem prepared to forgive him for as there have been no adverse stories on the issue (Malaysia's most controversial movie ever, 2008). Now with his celebrity profile raised, Ishak appears to be more discriminating in his acting decisions. In April 2013, he withdrew from acting in the theatrical production of Madame Butterfly, citing his management's disagreement with the 'political and sexual content of the production'. Ishak had clearly become aware of his role as a celebrity and conscious of his audience approval and support.

\section{Fandom and the receptive audience}

It would be true to say that fans are the fuel that keeps the celebrity fires burning. Product endorsements only work because the celebrity fan base supports an actor's popularity and the products bearing his name. Their role should not be underestimated as they not only follow their idols' social pages but also blog about their stars for increased popularity and visibility. Google searches show Khan to have 38.3 million fan sites, six times more than his Twitter following. His leading lady, Katrina Kaif has 31.8 million fan sites while Priyanka Chopra has 22 million. The Malaysian star of Aku Terima Nikahnya, Adi Putra, has 628,000 fan sites and his leading lady, Nora Danish, scores 624,000 . Whatever their numbers, fans ensure continuity of positive news stories as they engage with their celebrities for good news and 


\section{CELEBRITY AND SCANDAL}

blog about them. It is important for celebrities to live up to their fans' moral expectations as fans are most likely to defend their celebrities' reputation in times of crisis. For example, a study on young Asian consumers shows that when a celebrity is involved in a moral crisis with social repercussions, they are absolved of blame, if the attribution is considered external, and blamed, if it is considered internal:

This suggests that where consumers view a celebrity as responsible for their own actions, then they directly blame the celebrity for damage to society, alternatively where the consumer views the celebrity as a victim of circumstance then they take the view that damage to society is out of the celebrity's control, neither enhancing or detracting from their level of moral reputation. (Zhou \& Whitla, 2013, p. 1018)

With product endorsement being a generous means of celebrity income, this study has serious implications for celebrities who are often in tabloid media. Celebrities, like Ishak, need to be mindful of moral decisions made that could impact on society's views. As brand ambassador for Dashing men's fragrance, Ishak is now more discriminating about the parts he plays. In the event of negative publicity, Zhou \& Whitla (2013) advise that 'the celebrity should therefore encourage in the public mind an external locus of attribution for their actions as well as attempt to minimise the perceived impact on society at large' (p. 1018).

As lifeblood of the celebrities, fans are often eager to please their favourite stars, dedicating fan clubs and blogs. Often young and impressionable, they are easily influenced by the celebrity's pop culture, including their dress, mannerisms, style and behaviour. As the study of high school students in Delhi (Vasan, 2010) shows, male students tend to imitate the speech and teasing styles of their favourite celebrities from romance movies. As receptive audiences, fans who support the Asian romance movies that typecast their celebrities may well be conditioned to accept the culturally loaded moral messages, framed by media producers with celebrity support. While these messages strive to reinforce the perceived cultural hegemony, they may inadvertently silence the voices of the minorities such as the homosexual Dean in Student of the Year. 


\section{Conclusion}

The scandals portrayed in some Asian movies indicate that art forces itself on life and also mirrors it. These movies tell the stories of Asians addressing their moral values, their sense of religious, cultural and national identity as well as the meanings they attach to family and society. The characters must navigate their own moral compasses, reflecting the Asian culture in transition. Voices that rise against social norms are quietly appeased as if introduced to a sense of self-discovery such as the female traveller in Istanbul Aku Datang who questions social propriety and the hero in Hello Stranger with an aversion to marriage.

Scandals in fiction seem to translate to real life when actors find themselves agreeing to behave in ways that compromise their personal comfort for moviemaking. Off screen, some actors court tabloid news with their out-of-character behaviour, sending mixed signals to the press. Such negative publicity can damage their moral reputation and compromise brand endorsements unless they work with their fan base to clear their name from internal attribution error. It would also do celebrities good to remember that their young fans are devoted to the spread of positive news stories and are likely to reinforce their popularity by imitation and adoration. As audiences, young fans may be more receptive to the moral messages, which they see as representative of the romantic couple's answers to moral dilemmas.

In Asian movies, scandals are portrayed to highlight a deviance from the norm and the movies work to find a resolution as they bring back the familiar and accepted, acknowledging new perspectives without compromising social acceptance. As the characters struggle with moral decisions, the 'conscience collective' is upheld. 'Collective representation' is also present in the social settings, imbued with national and cultural influences such as the Thai village in First Love, the Indian military base in Jab Tak Hai Jaan and the Malaysian flag in Istanbul Aku Datang. As the story unfolds in multiple dramatic twists, Durkheim's 'collective effervescence' applies, culminating in the audiences' heightened emotional social experience of the romance movies, further diffusing their moral messages through the media representations of popular culture 


\section{CELEBRITY AND SCANDAL}

\section{References}

Alex, L. (2011). Collective effervescence. In SAGE Key Concepts: Key concepts in classical social theory. (pp. 50-55). London: Sage Publications.

Ciecko, A. T. (2006). Theorising Asian cinema. In A. T. Ciecko (ed.). Contemporary Asian cinema: Popular culture in a global frame. United Kingdom: Oxford International Publishers

Durkheim, E. (1995). The Elementary forms of religious life. (K.E. Fields, Trans.). New York, NY: Free Press. (Original work published 1912).

Hellmueller, L. C., \& Aeschbacher, N. (2010). Media and celebrity: Production and consumption of 'well-knownness'. Communication Research Trends, 29 (4), pp. 3-35.

Höijer, B. (2011). Social representations theory: A new theory for media research. Nordicom Review, 32 2, pp. 3-16.

Indo-Asian News Service (November 16, 2012). Why Shah Rukh Khan broke his kissing rule for Jab Tak Hai Jaan. Indo-Asian News Service. Retrieved August 31, 2013, from http://movies.ndtv.com/bollywood

Khan, R. A. (Jan 18, 2012). Exclusive pictures of Shah Rukh Khan and Priyanka Chopra's 3am friendship. Firstpost Bollywood. Retrieved August 31, 2013, from http://www.firstpost.com/bollywood/srk-and-priyanka-chopras-3am-friendship-186761.html

Malaysia's most controversial movie ever. Unconventional world records. Retrieved January 8, 2008, from http://worldrec.info/2008/01/08/malaysias-most-controversial-movie-ever/

Migration and Remittances Factbook (2011). Top remittance-receiving countries, 2010. Development Prospects Group, World Bank, p. 13. Retrieved August 31, 2013, from http://siteresources.worldbank.org/INTPROSPECTS/Resources/334934-1199807908806/Top10.pdf

Moscovici, S. (2000) Social representations: Explorations in social psychology. Cambridge, UK: Polity Press.

Rahman, K., \& Thomas, M. (2011). The media as an instrument of change. In R. E. Khan (Ed.), Media and culture: Global homogeneity and local identity. Mandaluyong City, Philippines: Anvil Publishers.

Rahman, K. (2013). Tearing and restoring the moral fabric of society in Asian romance movies. Asian Media Information and Communication Conference 2013 Proceedings. Retrieved August 31, 2013, from http://amic.org.sg/conference/AMIC2013/

Shah Rukh Khan: Top 15 controversies he has courted (June 18, 2013). Hindustan Times, New Delhi. Retrieved August 31, 2011, from http://www.hindustantimes. com/Entertainment/

The Economist. (Oct 21, 2009). Videographic: Migration. Retrieved August 31, 2013, from http://www.audiovideo.economist.com

Vasan, A. (2010). Films and TV: Viewing patterns and influence on behaviours of college students. Health and population innovation fellowship programme working paper, 13. New Delhi: Population Council.

120 PACIFIC JOURNALISM REVIEW 19 (2) 2013 
World Health Organisation (2001). Bollywood: Victim or ally? A study on the portrayal of tobacco in Indian cinema. World Health Organisation, Geneva, Switzerland.

Zhou, L., \& Whitla, P. (2013). How negative celebrity publicity influences consumer attitudes: The mediating role of moral reputation. Journal of Business Research, 66, 1013-1020.

Khairiah A Rahman is a senior lecturer at AUT University in Auckland where she lectures in intercultural communication and public relations. She is national director (New Zealand) for the Asian Congress for Media and Communication. Khairiah has written articles and book chapters on transnational identities, crisis miscommunication, intercultural trust relationships, curriculum development for industry, dialogue in public relations and the impact of media on culture.

khairiah.rahman@aut.ac.nz

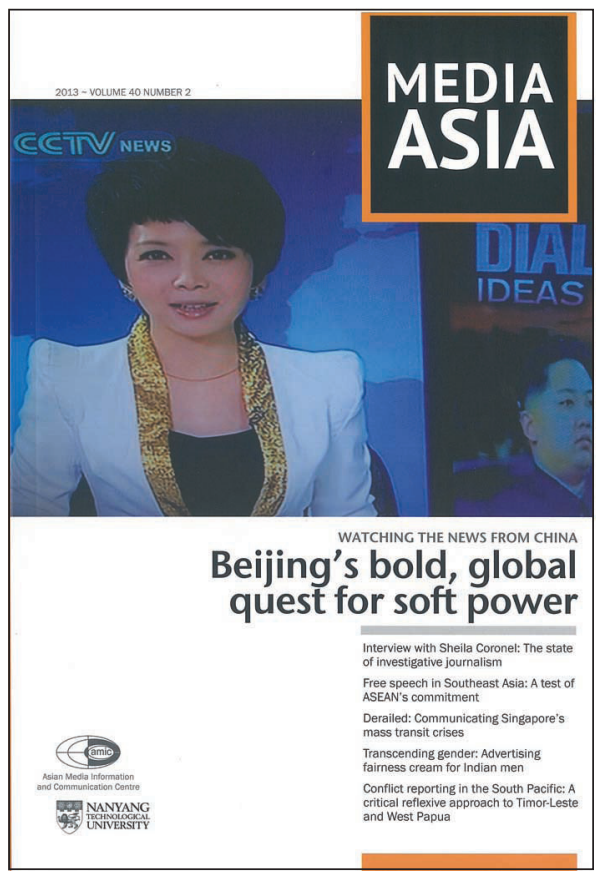

The new Media Asia (Volume 40,2013 ) aims to serve readers who are interested in harnessing reliable research and credible, critical insights in order to address contemporary media and communication challenges in Asia.

Feature:

- Research articles

- Essays

- Opinion papers

- Interviews

Subscription order/enquiry: publications@amic.org.sg

Correspondence:

AMIC, Jurong Point PO Box 360

Singapore 916412

Tel: +65 67927570

Website: www.amic.org.sg

PACIFIC JOURNALISM REVIEW 19 (2) 2013121 